NBER WORKING PAPER SERIES

\title{
WHO SHALL LIVE AND WHO SHALL DIE? AN ANALYSIS OF PRISONERS ON DEATH ROW IN THE UNITED STATES
}

\author{
Laura Argys \\ Naci Mocan \\ Working Paper 9507 \\ http://www.nber.org/papers/w9507 \\ NATIONAL BUREAU OF ECONOMIC RESEARCH \\ 1050 Massachusetts Avenue \\ Cambridge, MA 02138 \\ February 2003
}

Paul Niemann, Kaj Gittings, Norovsambuu Tumennasan and Benjama Witoonchart provided excellent research assistance. The views expressed here are those of the authors, and do not reflect those of the University of Colorado at Denver or the National Bureau of Economic Research. The views expressed herein are those of the author and not necessarily those of the National Bureau of Economic Research.

C2003 by Laura Argys and Naci Mocan. All rights reserved. Short sections of text not to exceed two paragraphs, may be quoted without explicit permission provided that full credit including notice, is given to the source. 
Who Shall Live and Who Shall Die?

An Analysis of Prisoners on Death Row in the United States

Laura Argys and Naci Mocan

NBER Working Paper No. 9507

February 2003

JEL No. K4, J18

\begin{abstract}
Using data on the entire population of prisoners under a sentence of death in the U.S. between 1977 and 1997, this paper investigates the probability of being executed on death row in any given year, as well as the probability of commutation when reaching the end of death row. The analyses control for personal characteristics and previous criminal record of the death row inmates. We link the data on death row inmates to a number of characteristics of the state of incarceration, including variables which allow us to assess the degree to which the political process enters into the final outcome in a death penalty case.

Inmates with only a grade school diploma are more likely to receive clemency, and those with some college attendance are less likely to have their sentence commuted. Blacks and other minorities are less likely to get executed in comparison to white inmates. Female death row inmates and older inmates are also less likely to get executed.

If an inmate's spell on death row ends at a point in time where the governor is a lame duck, the probability of commutation is higher in comparison to a similar inmate whose decision is made by a governor who is not a lame duck. If the governor is female, she is more likely to spare the inmate's life; and if the governor is white, the likelihood of dying is higher in comparison to the case where the decision is made by a minority governor.
\end{abstract}

\section{Laura Argys}

University of Colorado at Denver

Department of Economics, Box 181

Campus Box 173364

Denver, CO 80217-3364

largys@carbon.cudenver.edu
Naci Mocan

University of Colorado at Denver

Department of Economics, Box 181

Campus Box 173364

Denver, CO 80217-3364

and NBER

nmocan@carbon.cudenver.edu 
Who Shall Live and Who Shall Die?

An Analysis of Prisoners on Death Row in the United States

\section{Introduction}

Though the facade of the United States Supreme Courthouse assures "Equal justice under law," many observers of the U.S. legal system are concerned that biases lead to unfair treatment in the courts based on race, social class or gender. In 2000, about 47 percent of all inmates in state prisons were black, although they accounted for only 12 percent of the U.S. population (U.S. Census Bureau, 2000). In the same year, 94 percent of inmates in state prisons were male (U.S. Department of Justice 2002), even though just under half of the population was male.

These raw statistics alone do not imply discrimination against blacks or males. For example, blacks may be legitimately over-represented in the prison population if they are more likely to engage in criminal activity. Arrests of black suspects constituted about 28 percent of all arrests in 2000, and 49 percent of all suspects arrested for murder and nonnegligent manslaughter in the same year were black (U.S. Department of Justice 2002).

The prison population under sentence of death is also characterized by race and gender compositions which differ markedly from the U.S. population. Specifically, in 2000, about 43 percent of all death row inmates were black, and 98.5 percent were male (U.S. Department of Justice 2000). These patterns, combined with the irrevocable nature of execution, have prompted concerns over inequitable differences in the application of the death penalty in the United States. In 1972 the U.S. Supreme Court ruled that the administration of the death penalty at that time was unconstitutional because there was no justifiable basis for determining who would live and who would be sentenced to die. States responded in the mid-1970s by enacting revised legislation that addressed the Supreme Court's concerns, allowing capital 
punishment to resume.

However, capricious application of the death penalty, and racial discrimination specifically, remain widely-debated topics. In part because of the recent increase in executions and some highly publicized cases, objective use of the death penalty has become an important item on the national political agenda. In addition to political activists (e.g. Jackson 1996), many state legislators and governors have voiced concerns over the application of death penalty, and a bill was introduced in the U.S. congress to abolish the death penalty under federal law.

In this paper, using a data set compiled by the U.S. Department of Justice, we investigate discrimination in capital punishment cases after sentencing. By examining the entire population of inmates under a sentence of death between 1977 and 1997 we analyze whether there are race and ethnicity or gender differences in the outcomes of these cases. The probability of receiving a death sentence may depend on a number of factors, such as the characteristics of the case, the quality of the defendant's representation, racial composition of the jury and the conduct of the prosecutor and the judge. However, given that a death sentence is imposed, race and gender should not impact the probability of execution. The conditions under which this may not be the case are discussed in Section III.

We link the data on death row inmates to a number of characteristics of the state of incarceration, including variables which allow us to assess the degree to which the political process enters into the final outcome in a death penalty case. Although conviction and sentencing are largely outside of the political arena, state governors potentially play an important role in the ultimate resolution of a death penalty case. A governor may choose to 2001; S191. 
commute the sentence of a prisoner who is awaiting execution, and political motivation may play a role in this decision. Specifically, we investigate whether the timing and results of gubernatorial elections, and the race, gender and party affiliation of the governor have an influence on the probability that a prisoner under capital sentence is executed.

We find that the age and education of the inmate have an impact on the probability of commutation. More importantly, the race and gender of the death row inmate are determinants of whether he/she is executed or commuted. Furthermore, the race and gender of the governor and whether the governor is a lame duck influence the executioncommutation decision.

In Section II we provide a brief history of the death penalty in the United States. Section III discusses prior research and some conceptual issues; Section IV presents the model and the empirical methodology. Section V describes the data, the results are presented in Section VI, and Section VII concludes the paper.

\section{The Death Penalty in the United States}

Figure 1 illustrates the time-series pattern of executions in the United States between 1930 and 2002 During this time period 4,542 individuals were executed in the United States, with the bulk of the executions occurring in the 1930s and 1940s and declining through 1967. A Supreme Court decision suspended executions between 1970 and 1977, but there has been a steady increase in executions since 1977. There were three executions in the United States between 1977 and 1980. The number of executions increased to 47 during the period of 198185 , and to 93 in 1986-1990. In the first half of the 1990 s there were 170 executions, and the number of executions more than doubled in the second half of the decade (1996-2000) to 370. 
It should be noted, however, that this positive trend in executions since the early 1980s can be attributed to the increase in population and the increase in homicides that took place between 1970s and 1990. Specifically, the rate of executions is much lower than the one that prevailed in early-to-mid $20^{\text {th }}$ century. For example, in 1930 there were approximately 1.5 executions per million people. The rate was 0.5 executions per million people in early 1950s, and 0.3 executions per million people in the late 1990s. When the number of executions was rising between mid-1970s and 1990, so was the homicide rate. The rate of murder and nonnegligent manslaughter was 7.87 per 100,000 population in 1970 , and it increased to 9.42 in 1990.

In the late 1960s 40 states had laws authorizing use of the death penalty. However, strong pressure by those opposed to capital punishment resulted in few executions. Executions were halted and hundreds of inmates had their death sentences lifted by a Supreme Court decision in 1972. In Furman v. Georgia, 408 U.S. 153 (1972) the Supreme Court struck down federal and state laws that had allowed wide discretion resulting in arbitrary and capricious application of the death penalty. Three of the Supreme Court justices voiced concerns that included the appearance of racial bias against black defendants. Furthermore, laws that imposed a mandatory death penalty and that allowed no judicial or jury discretion beyond the determination of guilt were declared unconstitutional in 1976 [Woodson v. North Carolina, 428 U.S. 280 (1976), Roberts v. Louisiana, 428 U.S. 325 (1976)].

Starting in mid-1970s, many states reacted by adopting new legislation to address the concerns of the Supreme Court, and the new state laws were upheld by the Supreme Court

2 Obtained from Bureau of Justice Statistics. 
[e.g. Gregg v. Georgia, 428 U.S. 153 (1976), Jurek v. Texas, 428 U.S. 262 (1976), and Proffitt v. Florida, 428 U.S. 242 (1976)]. New state statutes created two-stage trials for capital cases, where guilt/innocence and the sentence were determined in two different stages. The first post-Gregg execution took place in 1977, and the number of executions continues to rise.

Figure 2 displays the proportion of death row prisoners who are white, black and of other race since $1968^{3}$. The proportion of whites remained stable around 48 percent of all death row inmates between 1968 and 1977. It started rising in 1977, reaching a plateau of 58 percent in early 1980s. During the same time period the proportion of black prisoners under the sentence of death declined from 54 percent to 42 percent. Visual inspection suggests that these changes might be due to the reaction of the justice system to the Supreme Court's scrutiny of racial disparities between blacks and whites. More precisely, the graph is consistent with the hypothesis that when capital punishment became legal following the fiveyear period during which it was deemed unconstitutional by the Supreme Court, the judicial system reacted by prosecuting whites more stringently than blacks after 1976 to avoid further scrutiny. We lack sufficient pre-1968 data to perform a statistical analysis to investigate whether the jump in the proportion of white death row inmates and the accompanying decline in the rate of blacks can be attributed to random noise, but the time-series depicted in Figure 2 is certainly suggestive of some structural change in the late 1970's. If that is indeed the case, it would suggest that the judicial system exerts substantial discretion as to the racial composition of the death row population.

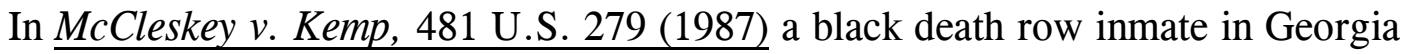

3 Whites and Hispanics are combined in this graph. 
argued that black defendants convicted of killing white victims were more likely to be given the death sentence than other defendants. Although the court acknowledged that there was a system-wide correlation between the victim's race and the imposition of the death penalty, the defendant had not met the burden of proving that his individual sentence was based on the race of his victim. The Racial Justice Act proposed in the U.S. House of Representatives in 1994 was an attempt to allow prisoners to appeal their capital sentences using statistical evidence of bias. Though it passed in the House, it was defeated in the Senate. Recently, a bill was introduced in the U.S. Congress to abolish the death penalty under Federal Law legislators in at least 21 states have recently proposed legislation to modify their existing capital punishment laws, and governor George Ryan imposed a moratorium on executions in the state of Illinois in 2000 .

\section{Previous Research and Theoretical Background}

The overwhelming majority of a very extensive law literature, and a sizable literature in social sciences point to the influence of the defendant's race as well as the race of the victim on the imposition of the death penalty (Zeisel 1981, Steiker and Steiker 1995, Paternoster 1984, Kleck 1981, Wolfgang and Riedel 1973, Pokorak 1998, Baldus et al. 1998, Gross and Mauro 1984. For example, Baldus et al. (1998) find that after controlling for the criminal record of the defendant and the severity of the crime, blacks are almost four times more likely to receive the death sentence. Similarly, research suggests that females face preferential treatment in sentencing in a capital murder case even after controlling for criminal history and excessive cruelty (Raport, 1991).

4 Supra note 1. 
It has been argued that the probability of imprisonment should vary with the wealth of the individual (Lott 1987). This is because the size of the penalty a criminal actually receives depends on the length of imprisonment, the opportunity cost of imprisonment (e.g. foregone income), and the money spent on defense. An increase in any of these factors increases actual punishment. If the length of imprisonment given conviction is fixed, then obtaining the optimum expected penalty can be achieved by a reduction in the probability of conviction for individuals with higher opportunity costs. This argument suggests that if prison terms are set with respect to the nature of the crime alone, the correct expected penalty can be achieved only if people with high opportunity costs are allowed to buy legal services that would reduce their probability of conviction (see also Lott 1992).

The argument that a wealthier group of people (e.g. whites) may reduce their probability of conviction through the purchase of better legal services generates an extreme implication in capital cases: the value of life of a member of a certain group is greater than others. Although the present discounted value of a lifetime income stream can be calculated fairly easily, it is not straight-forward to assess the value of life in general. Furthermore, the possibility of discrimination (conditional upon the optimal expected punishment) has obviously more serious implications in the case of the death penalty.

An inherent problem in identifying discrimination in empirical analysis is the inability of the researcher to account for "unobservables." For example, in the case of the death penalty it may be difficult to account for all the aggravating and mitigating circumstances of a case. If these difficult-to-observe attributes of the case (for the researcher) are correlated with race, they may explain the apparent racial differences. Even though researchers attempt 
to capture these difficult-to-observe idiosyncrasies of murder cases, the courts remain unconvinced that the race disparity is due to discrimination and not due to omitted unobservable case characteristics (Baldus et al. 1998).

As discussed in the introduction, race and gender should not be related to the outcomes on death row in the absence of discrimination, with two exceptions. First, it can be argued that race may be correlated with wealth, and wealthier prisoners may have a better chance to reverse their conviction through the appeals process. In the absence of a measure of wealth, race may act as a proxy for it in statistical analysis. This suggests that minorities (the less wealthy group) are expected to have a higher probability of execution, given conviction. Although this point has merit, a counter-argument can be made. If wealth is expected to influence the outcome of the appeal, it is meaningful to expect it having even a larger impact on the outcome of the original trial. Put differently, variations in wealth would probably have a smaller impact on the outcome of the appeals in comparison to the outcome of the original trial. Everyone in our analysis is convicted of murder. Thus, most (but probably not all) of the impact of wealth on acquittal has been filtered out before the individuals reach death row.

The second channel though which race may impact the outcome on death row is discrimination before the prisoner reaches death row. If minorities are subject to discrimination during the murder trial, this suggests that some minorities reach death row with questionable guilty verdicts, which in turn suggests that white prisoners on death row could be thought of as "more guilty" on average. Thus, conditional upon conviction, minorities under the sentence of death should have a lower probability of being executed. 
The political environment of the state may have an influence on the outcome of dyingor-living on death row. For example, a strong public sentiment against the death penalty may put pressure on the governor to commute the inmate. Similarly, governor's own ideology may impact his/her decision to grant a commutation to a death row inmate. Pridemore (2000) finds that Democratic governors are more likely to execute during the period of 1978 to1995. Kubik and Moran (2002) investigate the impact of the gubernatorial election cycle on the existence of executions in a state. They find that a state is more likely to conduct an execution in an election year.

We investigate whether personal characteristics of the governor, such as the governor's race and gender, impact who dies and who lives among death row inmates. We also analyze whether the lack of political pressure on the governor has an influence on the governor's decision to grant a commutation. Specifically, we analyze whether being a lameduck governor has an impact on the decision to let the inmate live or die.

\section{$\underline{\text { IV. Empirical Specification }}$}

Conditional on being convicted, the severity of punishment, measured by the execution of prisoners under the sentence of death, can be modeled as

$$
\Omega_{\mathrm{i}}=f_{l}(\mathrm{X}, \mathrm{E}, \mathrm{G},)
$$

where $\Omega_{\mathrm{i}}$ stands for the execution probability of the $i$ th criminal, $\mathrm{X}_{\mathrm{i}}$ represents the personal characteristics of the criminal, including race, gender, marital status and criminal history. E captures exogenous cultural and socio-economic characteristics of the state where the criminal is in custody. These characteristics include, among others, the age, race and religious composition of the state, the unemployment and urbanization rates. 
The vector $\mathrm{G}$ represents the characteristics of the governor of the state and the political environment surrounding the governor. They include the race and gender of the governor, the party affiliation of the governor, and whether the governor is a lame-duck at the time when s/he makes the decision to commute the inmate.

We estimate equation (1) in two different ways. First, we create a data set that includes all prisoners under sentence of death between 1977 and 1997. Each prisoner contributes one observation for each year in which they are on death row and therefore at risk of execution. The dependent variable is dichotomous, equal to one if the prisoner is executed in that year, and zero otherwise. This stacked-logit model, estimated by maximum likelihood, is the discrete-time version of a continuous hazard model. The results provide estimates of changes in the annual probability of execution while on death row. In this specification the alternative to execution is all other outcomes on death row, ranging from having one's sentence being overturned to dying by natural causes (see table 2). Thus, political variables should have no impact on the probability of execution in any given year.

The second set of models estimates the same equations for those who completed their duration on death row. The terminal event is either execution or commutation at which time the governor has the authority to grant clemency. ${ }^{\mathrm{B}}$ It is at this point that personal preferences and political motivation of the governor are expected to be most evident. Using the sample of prisoners who are either executed or commuted, maximum likelihood probit models are estimated to investigate the probability of the sentence being commuted. Thus, in these models we analyze the probability of a prisoner's sentence being commuted given that all legal appeals have been exhausted.

5 In some states the Board of Pardons and Paroles' favorable recommendation is needed to commute 
Even though the data set does not contain wealth information on the prisoners on death row, it contains information on their age at sentencing, and education. To the extent that age and education are correlated with wealth, in empirical analyses we control for some of the wealth effect. When a prisoner under the death sentence exhausts all means of reversing the sentence, the two possible outcomes are execution and commutation. At this stage, wealth of the prisoner should have no impact on the outcome.

\section{$\underline{\text { V. Data }}$}

We use data from Capital Punishment in the United States, 1973-1997, collected by the U.S. Department of Justice. This data set contains information on the 6,819 death sentences handed down between 1973 and 1997 in the United States. Because some prisoners receive multiple sentences, this represents 6,465 unique prisoners. From the original sample, we exclude 243 prisoners whose status as of December 31, 1997 is not reported in the data. We also eliminate the 417 prisoners who were removed from death row prior to 1977. In order to examine the effects of political variables and gubernatorial actions, we exclude 16 prisoners who are in federal prison or the District of Columbia. Thus, our data set consists of 5,779 inmates under sentence of death in the post-Gregg era between 1977 and 1997. The data set includes socio-demographic information at the time of incarceration. There is also information on the inmate's criminal history and additional information is provided on those who were removed from death row by the end of 1997 .

the sentence. In case of clemency, the sentence is commuted into a prison term, typically life.

${ }^{6}$ U.S. Dept. Of Justice, Bureau of Justice Statistics. Capital Punishment in the United States, 1973-1997 [Computer file]. Compiled by U.S. Dept. of Commerce, Bureau of the Census. ICPSR ed. Ann Arbor, MI: Inter-university Consortium for Political and Social Research [producer and distributor]. 
Figure 3 displays the number of prisoners on death row between 1977 and 1997.

Over the course of the two decades the number of prisoners on death row increased more than seven-fold. This increase is consistent with the rise in the general prison population. During the same time period the number of prisoners under federal and state jurisdiction almost quadrupled to about 1.4 million inmates. The national violent crime rate increased from 476 violent crimes per 100,000 people in 1977 to about 750 in early 1990s. It then started exhibiting a continuous decline to about 525 per 100,000 people in 1999 . Murders and non-negligent manslaughters shared the same trend. The total number of murders and non-negligent manslaughters was 19,120 in 1997 . It increased to 24,700 in 1991 , and then declined to 15,530 in 1999.

The empirical counterpart of Equation (1) includes demographic characteristics of the prisoner (i.e. gender, race, ethnicity, age, education and marital status), and his or her criminal and prison history (prior felony convictions, the duration on death row, and the number of times sentenced) as components of $\mathrm{X}_{\mathrm{i}}$. Specifically, we include dichotomous variables to classify each prisoner into one of three racial categories: white, black and of other race. ${ }^{日}$ Our data also include an indicator of Hispanic ethnicity. Because this variable is either reported as missing or not reported for just under ten percent of our sample, we create three ethnicity categories: Hispanic, Non-Hispanic and Missing Ethnicity. ${ }^{\mathrm{g}}$ Descriptive statistics for all 5,779 prisoners on death row between 1977 and 1997 are reported in Table 1 for all inmates and separately by race and ethnicity. ${ }^{\text {日 }}$ As column one of Table 1

\footnotetext{
7 the "other" category includes inmates reported to be American Indian or Alaskan Native, Asian or Pacific Islander, and other race.

8 It should be noted that a prisoner will be simultaneously classified as Hispanic and one of the racial categories.

9 The 5779 prisoners represent 6,126 death sentences, since 329 prisoners were sentenced multiple times.
} 
demonstrates, very few of those under sentence of death, (less than two percent) are female. Nearly 57 percent of death row inmates are white, about 42 percent are black, and less than two percent are of other race. Just over seven percent report being Hispanic, and nearly 10 percent have missing ethnicity information. The remaining 83 percent are identified as nonHispanic. Not surprisingly, education levels of death row inmates are low: just under half of the prisoners on death row have less than a high school education and only eight percent have attended college. At the time of initial sentencing, the average inmate was nearly 30 years of age, and one-fourth were married. There are some differences between the racial and ethnic groups depicted in the last four columns of Table 1. Most notably, blacks are younger on average and have lower levels of education.

The lower panel of Table 1 reports the criminal history and duration on death row. Nearly all of the inmates received their capital sentence for committing murder. In addition, the majority (59\%) were convicted of at least one felony prior to the commission of their capital crime. Black prisoners are more likely to have a prior felony conviction. These differences in criminal history may legitimately result in differences in the resolution of the death penalty.

Finally, Table 1 identifies the length of stay on death row. The average inmate has spent over six years under a sentence of death. This figure includes those whose spell on death row has ended, either through the removal of their sentence, death in prison or execution as well as those who are still on death row. For those still on death row at the end of our sample period the duration is calculated as the number of calendar years between sentencing and the end of our sample period in 1997. For those who were removed from death row the duration is calculated as the difference between the year they were removed and the year that they were sentenced. 
Figure 4 displays the behavior of average duration on death row between 1977 and 1997 for those who faced the terminal event (execution or commutation). As Figure 4 demonstrates, the duration on death row is increasing over time. For example, the average duration was 6 years in 1983, and it went up to 8 years in 1990, and it was 11 years in 1997. The same trend pertains to those who are executed. As Figure 5 shows, the average waiting time on death row for those who were ultimately executed was around 4 years in early 1980s; it went up to about 11 years in 1997.

Table 2 summarizes the status of the 5,779 death row inmates as of December 31 , 1997. The first row identifies the fraction of inmates who remained under a sentence of death as of that date. Approximately 57 percent of all prisoners remained on death row. There are some ethnic differences in this proportion. For instance, a larger proportion of Hispanics, 67 percent, were still on death row at the end of 1997, while only 56 percent of white prisoners remained on death row.

The lower panel of Table 2 reports the outcome for prisoners who were removed from death row before the end of 1997. It is noteworthy that among those who have reached the final disposition of their death sentence, only about 17 percent have been executed. This proportion is even lower for blacks (16 percent) and those of other race (14 percent). After initial sentencing, legal representatives typically pursue a variety of appeals on behalf of their clients. About 61 percent of those who left death row had done so because their sentence or conviction was overturned. The remainder of those leaving death row did so because they died in prison (6.4 percent), had their sentence commuted (4.9 percent), had their sentenced deemed unconstitutional (8.3 percent). A very small fraction (1.8 percent) had their sentence removed for other reasons. Figure 6 exhibits the number of state prisoners who are executed 
or commuted between 1977 and 1997. As the number of prisoners who are commuted remained stable since mid-1980s, the number of executions increased, reaching 74 executions in 1997.

Table 3 displays the characteristics of the governor and the state that are included in the analyses. Because the sample sizes are different between the two analyses we perform, the means of the variables are not identical in both samples. White governor is a dichotomous variable, equal to 1 if the governor is white, and zero otherwise. For stacked-logit models where the unit of observation is every year that an individual prisoner is under sentence of death awaiting execution, the relevant political variables include a set of dichotomous variables indicating the characteristics and political circumstances of the governor. They are: Democrat, which is equal to 1 if the governor is Democrat; Election Year, equal to 1 if the death row inmate is at risk of execution during an election year; Governor not elected, another dummy variable equal to 1 if the incumbent governor lost re-election in November of that year and was a lame duck between the election date and December 31 of the same year as a lame duck; and Governor leaves, another dummy variable equal to 1 in that year to capture the lame-duck period between January 1 and the inauguration of the new governor.

In the model where the governor's decision to allow execution or commution is analyzed, the unit of observation is no longer a full year. In this model we are able to more precisely link the date of the event (execution or commutation) to the exact political circumstances. More specifically, we include a dichotomous variable, Lame Duck, which is equal to 1 if the governor is a lame duck at the exact date when he/she made the execution/commutation decision. This includes the time period between a gubernatorial election in November and the inauguration of the new governor in January, where the incumbent governor either did not run for reelection or was defeated. A second dichotomous 
variable, Up to 6 Months Before Election is equal to 1 if the execution or commutation took place in the period 6 months prior to an election.

State characteristics are the unemployment rate, the proportion of the state population in the following age groups: 15-19, 20-24, 25-34, 35-44, 45-54 and 55 and over, the proportion of the state in urban areas, the racial and ethnic composition of the state, per capita consumption of malt beverages (Beer consumption); a set of dummy variables for the legal drinking age in the state; the proportion of state population that is Catholic, Southern Baptist, Mormon, and Protestant.

\section{Empirical Results}

\section{Probability of Execution in Any Year}

Table 4 presents the results from the stacked logit model. The reported marginal probabilities measure changes in the probability that a death-row inmate is executed in any one year. They are multiplied by 100 for ease of exposition. The marginal probabilities are small because the unconditional probability of being executed in any given year is one percent in the data.

In addition to personal characteristics of the inmate and state, our model includes characteristics of the governor (race, gender and political party affiliation), the variable to indicate whether a gubernatorial election occurred in that year (Election Year), and the two variables indicating that part of the year the governor was a lame duck (Governor not Elected and Governor Leaves).

Columns 1 and 2 of Table 4 display the model which includes region fixed effects; columns (3) and (4) display the results of the model with state fixed-effects. Put differently,

10 As explained below, we also experimented with different time windows. 
we control for unobserved differences between the nine regions of the country by including a set of region dummies for the model reported in columns (1) and (2); and the same is done with a set of state dummies where the death row inmate is in custody in columns (3) and (4).

Table 4 demonstrates that black death row inmates have a lower probability of being executed in any given year. This race differential is not surprising, because about 84 percent of all black inmates are removed from death row reasons other than execution (see Table 2). The gender and ethnicity of the inmate, his/her marital status and education have no impact. In this specification, alternatives to execution are the sentence or conviction being overturned, the sentence being found unconstitutional, the inmate dying on death row, and removals for other reasons. Given that the alternatives to being executed are so extensive and mostly determined outside of the governor's control, political variables should exert little influence on the probability of being executed. For example, it is not expected that governor's race or gender, or the presence of a gubernatorial election would impact the inmate's sentence being overturned in any year. Consistent with our expectations, controlling for state fixed-effects, governor's personal characteristics and election-related variables have no impact on the likelihood of being executed in any given year. ${ }^{\text {W }}$

Not surprisingly, as time on death row goes up, the probability of execution rises but at a diminishing rate. The number of spells on death row has a negative impact on the probability of execution in a given year, which may represent the impact of the weakness of the case against the inmate. An inmate with a record of prior felony convictions faces a higher probability of being executed in any given year in the model with state fixed effects.

11 This contradicts the finding of Kubik and Moran (2002) who report that a state is more likely to execute in an election year. 


\section{Execution vs. Commutation}

To investigate whether the race and gender of an inmate or gubernatorial politics have any influence on the probability of commutation versus execution, we focus on the sample of inmates who have reached their final decision and had not previously been removed from death row through the appeals process or death in prison. This is the sample of inmates who are either executed or commuted. The dependent variable is equal to one if the sentence is commuted and zero if the prisoner is executed. If there is no capricious application of the commutation process, the characteristics of the inmate (other than the circumstances of the case and criminal history of the inmate) should not influence the probability of clemency. We also include controls for personal characteristics of the governors (i.e. their race, gender, political party affiliation) as well as indicators of the gubernatorial election process. In this specification the event (execution or commutation) occurs at a particular date (rather than the entire year-at-risk of the previous model). Because we know the exact date of the event, we link it closely to the timing of elections. In particular, we include a variable indicating whether the execution-commutation decision of a particular inmate took place during the six months prior to an election. ${ }^{-2}$ If the governor wants to send a signal to voters as to the degree of his/her toughness on crime, then one would expect that it would be less likely for a governor to commute sentences before the election. ${ }^{12}$ In addition, we construct a variable indicating whether the governor is acting as a lame duck. This dichotomous variable is equal to one if execution-commutation decision took place during a month in which a governor was not re-elected in November and served until January of the next year.

12 We tried another specification defining an event occurring within the 10 months prior to the election and the results were unchanged.

13 Kubik and Moran (2002) have found that the annual probability that a state will conduct at least 
Marginal probabilities are reported along with z-statistics (based on robust standard errors, adjusted for clustering at the state level). Columns 1 and 2 in Table 5 report the regressions with region and state fixed effects, respectively. Consistent with our earlier results, the probability of clemency is higher for black prisoners and prisoners of other race compared to white prisoners. All else the same, females are more likely to have their sentence commuted in comparison to males. As discussed earlier, one cannot rule out the possibility that preferential treatment of minorities that emerges during the executioncommutation stage is a remedy for discrimination or irregularities during the arrest, trial, conviction and sentencing phases. It can similarly be argued that the gender effect that emerges from this analysis is not due to differential treatment, but rather due to specific characteristics of these cases. For example, murder cases against convicted females may be easier to forgive in comparison to other cases. If these cases are more likely to be "crimes of passion," and murders due to a "battered wife syndrome," rather than being vicious murders, commutation would be more likely. In that case, the significant female variable in the regression does not represent discrimination, but merely reflects the "weaker" characteristics of the cases involving females. To explore this possibility, we reviewed details of the cases for females who received clemency. Among the eight women who were commuted prior to 1997, the majority were convicted of violent murders, often in combination with other felonies. In only two of the cases were issues of past abuse or "battered wife syndrome" raised. Therefore, there is no strong evidence to substantiate the claim that females were more deserving of clemency based on the merits of their cases. 14

one execution is higher in election years.

14 In the past few years there have been some highly-publicized executions of female inmates. These executions represent a substantial increase over the low execution rates for women during the 20- 
Death row inmates with only a grade school education are more likely to have their sentences commuted compared to inmates with a high school diploma (the omitted category). On the other hand, an inmate with some college education is less likely to receive clemency. As the age of the prisoner at the time of sentencing goes up, the likelihood of having the sentence commuted goes down. Although the effect is non-linear, the negative impact of age on the probability of clemency does become zero until the age of 77 . The number of times the inmate was removed and re-sentenced to death (Number of Spells) has a negative impact on the probability of commutation, suggesting that having the sentence re-affirmed increases the chance of execution once appeals have been exhausted. Surprisingly, controlling for everything else, the existence of prior felonies has no significant impact. In models where prior felonies were replaced with the number of crimes committed by the inmate in conjunction with murder, the results did not change. Similarly, adding the number of crimes as an additional variable did not alter the results.

Table 5 also reveals that characteristics of the governor affect the probability of living and dying on death row. Column 2 , including state fixed effects, shows that if the governor is white, the probability of commutation is 55 percentage points less likely. ${ }^{\text {I. }}$ If the governor is female, the death row inmate who faces execution-commutation decision is 34 percentage points more likely to live. If the governor is a lame duck, he/she is 46 percentage points more likely to commute the sentence of a death row inmate.

year period that we study. This recent increase in female executions may signal a change in the preferential treatment we find afforded women on death row.

15 This, of course, means that if the governor is minority, the probability of commutation is 55 percent higher. 
The fact that an inmate faced the execution-commutation decision during the 6-month period before a gubernatorial election had no impact on his/her probability of execution. It is conceivable that the inmates who come up for execution-commutation decision during the 6month window before the election are less likely to live if that window is one in which the murder rate in the state is high. In other words, it is conceivable that the incumbent governor may want to send a signal to voters before the election if the murder rate in the state is high. However, interacting the Up to 6 months before election variable with the murder rate in the state did not provide any significant impact. Thus, we find no evidence that there is a direct impact of elections on the probability of commutation of the inmate.

To test the hypothesis that governors are more lenient toward death row inmates of their own race, we interacted the variable White Governor with a dummy variable which takes the value of 1 if the inmate is white. The results are reported in columns (3) and (4) of Table 5. The interaction term is positive, but not significantly different from zero, indicating that there is no statistical evidence that governors are more lenient towards a particular race. Other results do not change. ${ }^{\square}$ We could not test whether female governors are more lenient towards female inmates because there are no female death row inmates who faced a female governor for commutation-execution decision. Adding linear time trends to the models does not alter the results.

16 Using the data that cover 1978-1995 Pridemore (2000) finds no impact of an election year on the probability of execution, but reports a positive impact of facing a Democratic governor. His model does not include a lame duck variable or other state characteristics, and controls only for South-nonSouth distinction.

17 When we tested the same hypothesis by using a variable to indicate a Minority Governor and its interaction with minority inmate we found positive significant coefficients for both, implying that a minority governor is more likely to commute in general, and also more likely to commute a minority inmate. However, the estimated standard error was extremely small, implying that the identification of the impact did not have much power. 
These result are troubling as they indicate that who lives and who dies depends on personal (not criminal) characteristics of the inmate, and the personal characteristics of the governor and the political environment. More specifically, imagine two death row inmates who are in custody in the same state, who have the same criminal background (as measured by the presence of prior felonies), who are of the same age, who have same education and marital status. They face differential probabilities of dying if their race and gender are different. Furthermore, their likelihood of dying depends on the race and gender of the governor who determines their fate and whether the governor is a lame duck.

\section{Summary and Discussion}

The existence of the death penalty and the alleged discrimination against minorities in the application of the death penalty remains a contentious issue. The fact that minorities are over-represented in the population of prisoners under the sentence of death in comparison to their share in the U.S. population does not verify the existence of discrimination against them in the judicial system. This is because the rate of criminal activity may be higher for minorities, and/or minorities may not have access to high quality representation and defense because of wealth constraints. Discrimination exists if race is a determinant of receiving the death penalty after controlling for the characteristics of the case, such as the severity of the crime, criminal history of the defendant and the quality of the representation. Even though some research has demonstrated racial disparities in the probability of receiving the death penalty after controlling for case characteristics, the courts remain unconvinced, because a host of difficult-to-observe factors may be driving the apparent disparity. For example, it may be the case that the judicial system may be color-blind and unbiased with the exception 
of the jury. If the jurors act inequitably in an otherwise fair trial environment, racial disparities would emerge. Alternatively, prosecutors' racial biases may contaminate the system by influencing the outcome of guilty/not guilty plea process, by deliberately influencing the racial, ethnic and gender composition of the jury, among others. It is difficult to disentangle these factors and isolate the impact of race of the defendant on the likelihood of receiving the death penalty.

To circumvent potential bias caused by such unobservable factors, we adopt a different approach in this paper. We analyze the entire population of prisoners under a sentence of death in the U.S. between 1977 and 1997, and investigate the probability of being executed on death row in any given year, as well as the probability of commutation when reaching the end of death row. We control for age, education, marital status, previous criminal record of the prisoners, as well as a number of state characteristics where the death row inmate is in custody. Given that they already received the death penalty, prisoners' race or gender should not be a determinant of the probability of being executed, with one exception. Minorities on death row would have weaker cases against them if they were subject to discrimination in earlier stages. In this case, their probability of execution would be lower in comparison to their white counterparts, and a favorable treatment on death row may be to rectify irregularities that may have taken place at arrest, trial, conviction or sentencing phases. In all other circumstances the race of the inmate should not be related to the outcome of living and dying on death row at any point in time.

We also investigate whether or not the race and gender of the governor, the party affiliation of the governor and whether the governor is a lame duck (who was not reelected -whether he/she ran or not- and served out the full term until the newly elected governor 
took office in January) have any influence on the probability of being executed.

Our results show that, controlling for individual characteristics of the prisoner and the previous criminal record, the probability of an inmate being executed on death row in any year depends positively on the time spent on death row. The probability of being executed in any given year is smaller for blacks. In this analysis, the alternatives to execution are the sentence or conviction being overturned, the sentence being found unconstitutional, the inmate dying on death row, and removals for other reasons. As expected, given that the alternatives to being executed are so extensive and mostly determined outside of the governor's control, political variables and governor characteristics have no impact on the probability of being executed. For example, governor's race or gender, or the presence of a gubernatorial election have no influence on the inmate's execution probability in any year.

When we investigate the final outcome of execution versus commutation, very striking results emerge. Inmates with only a grade school diploma are more likely to receive clemency, and those with some college attendance are less likely to have their sentence commuted. As the age of the inmate at sentencing goes up, his/her probability of commutation goes down.

There are important race differences. Blacks and other minorities are less likely to get executed in comparison to white inmates. This may indicate pure preferential treatment of blacks and other minorities, or it may be an indication of reversal of discrimination that may have taken place earlier in the process. Female death row inmates are also less likely to get executed. This result cannot be justified as an act to rectify previous discrimination, because there is no evidence in prior research that females are discriminated against during 
trial, and murders committed by female death row inmates seem no less vicious than those committed by males during the time period covered by our analysis.

We find that if an inmate's spell on death row ends at a point in time where the governor is a lame duck, the probability of commutation increases by 46 percentage points over that of an otherwise similar inmate whose decision is made by a governor who is not a lame duck. Similarly, if the governor is female, she is 34 percentage points more likely to spare the inmate's life; and if the governor is white, the likelihood of dying is 55 percentage points higher in comparison to the case where the decision is made by a minority governor. These results are troubling, because they show that who lives and who dies on death row depends on factors unrelated to the characteristics of the case. Instead, the race and gender of the inmate, the race and gender of the governor and whether the governor is a lame duck determine who lives and who dies on death row, which violates the principle of "equal justice under law." 
Table 1

Descriptive Statistics for all Inmates on Death Row Between 1977 and 1997

by Race and Ethnicity

\begin{tabular}{|c|c|c|c|c|c|}
\hline & & Per & Characte & & \\
\hline & $\begin{array}{l}\text { Full } \\
\text { Sample }\end{array}$ & White & Black & Other Race & Hispanic \\
\hline Female $(\%)$ & 1.77 & 2.22 & 1.21 & 0.00 & 0.97 \\
\hline White $(\%)$ & 56.96 & 100 & 0.00 & 0.00 & 93.70 \\
\hline Black $(\%)$ & 41.51 & 0.00 & 100 & 0.00 & 4.36 \\
\hline Other Race (\%) & 1.52 & 0.00 & 0.00 & 100 & 1.94 \\
\hline Hispanic $(\%)$ & 7.15 & 11.76 & 0.75 & 9.09 & 100 \\
\hline Missing Ethnicity (\%) & 9.79 & 7.78 & 12.58 & 10.23 & 0.00 \\
\hline No High School (\%) & 14.88 & 15.37 & 14.05 & 19.32 & 21.31 \\
\hline Some High School (\%) & 32.25 & 29.04 & 36.81 & 28.41 & 37.53 \\
\hline High School Graduate (\%) & 29.54 & 30.95 & 27.47 & 32.95 & 18.40 \\
\hline Attended College $(\%)$ & 8.12 & 10.09 & 5.46 & 6.82 & 5.81 \\
\hline Missing Education (\%) & 15.21 & 14.55 & 16.22 & 12.50 & 16.95 \\
\hline Married at Sentencing (\%) & 25.16 & 26.88 & 22.72 & 27.27 & 26.63 \\
\hline Marital Status Missing (\%) & 8.48 & 7.69 & 9.59 & 7.95 & 6.54 \\
\hline Age at Sentencing & 29.64 & 30.96 & 27.81 & 30.33 & 28.43 \\
\hline & $(8.76)$ & $(9.29)$ & $(7.63)$ & $(8.52)$ & $(7.67)$ \\
\hline & $\mathrm{Cri}$ & al and $\mathrm{F}$ & listory & & \\
\hline Capital Offense Murder (\%) & 99.50 & 99.82 & 99.04 & 100 & 100 \\
\hline Prior Felonies (\%) & 58.70 & 56.83 & 61.57 & 50.00 & 51.33 \\
\hline Prior Record Missing (\%) & 8.84 & 8.72 & 9.13 & 5.68 & 10.90 \\
\hline Duration on Death Row & 6.33 & 6.40 & 6.26 & 5.83 & 6.14 \\
\hline & $(4.80)$ & $(4.80)$ & $(4.81)$ & $(4.64)$ & $(4.65)$ \\
\hline Sample Size & 5,779 & 3,292 & 2,399 & 88 & 413 \\
\hline
\end{tabular}

Standard deviations for continuous variables are in parentheses. 
Table 2

Final Disposition of Death Sentences for Inmates under Capital Sentence 1977-1997

\begin{tabular}{|c|c|c|c|c|c|}
\hline \multirow[b]{2}{*}{$\begin{array}{l}\text { Still On Death } \\
\text { Row }(\%)\end{array}$} & Full Sample & White & Black & Other Race & Hispanic \\
\hline & 56.97 & 56.29 & 57.80 & 60.23 & 67.07 \\
\hline \multicolumn{6}{|c|}{ Distribution (\%) of Those Who are Removed From Death Row } \\
\hline & Full Sample & White & Black & Other Race & Hispanic \\
\hline $\begin{array}{l}\text { Sentence or } \\
\text { Conviction } \\
\text { Overturned }\end{array}$ & 61.42 & 59.97 & 63.34 & 65.72 & 52.94 \\
\hline $\begin{array}{l}\text { Sentence Found } \\
\text { Unconstitutional }\end{array}$ & 8.29 & 6.46 & 11.17 & 0.00 & 5.15 \\
\hline $\begin{array}{l}\text { Died on Death } \\
\text { Row }\end{array}$ & 6.40 & 7.99 & 3.85 & 14.29 & 9.56 \\
\hline Other Removal & 1.79 & 1.60 & 1.87 & 0.00 & 1.47 \\
\hline Executed & 17.34 & 18.42 & 15.91 & 14.29 & 19.12 \\
\hline $\begin{array}{c}\text { Sentence } \\
\text { Commuted }\end{array}$ & 4.87 & 5.56 & 3.85 & 5.71 & 11.76 \\
\hline
\end{tabular}

Note: Other Removal combines those who were removed for unknown reasons and those who were moved to a mental institution. 
Table 3

Descriptive Statistics of State and Governor Characteristics

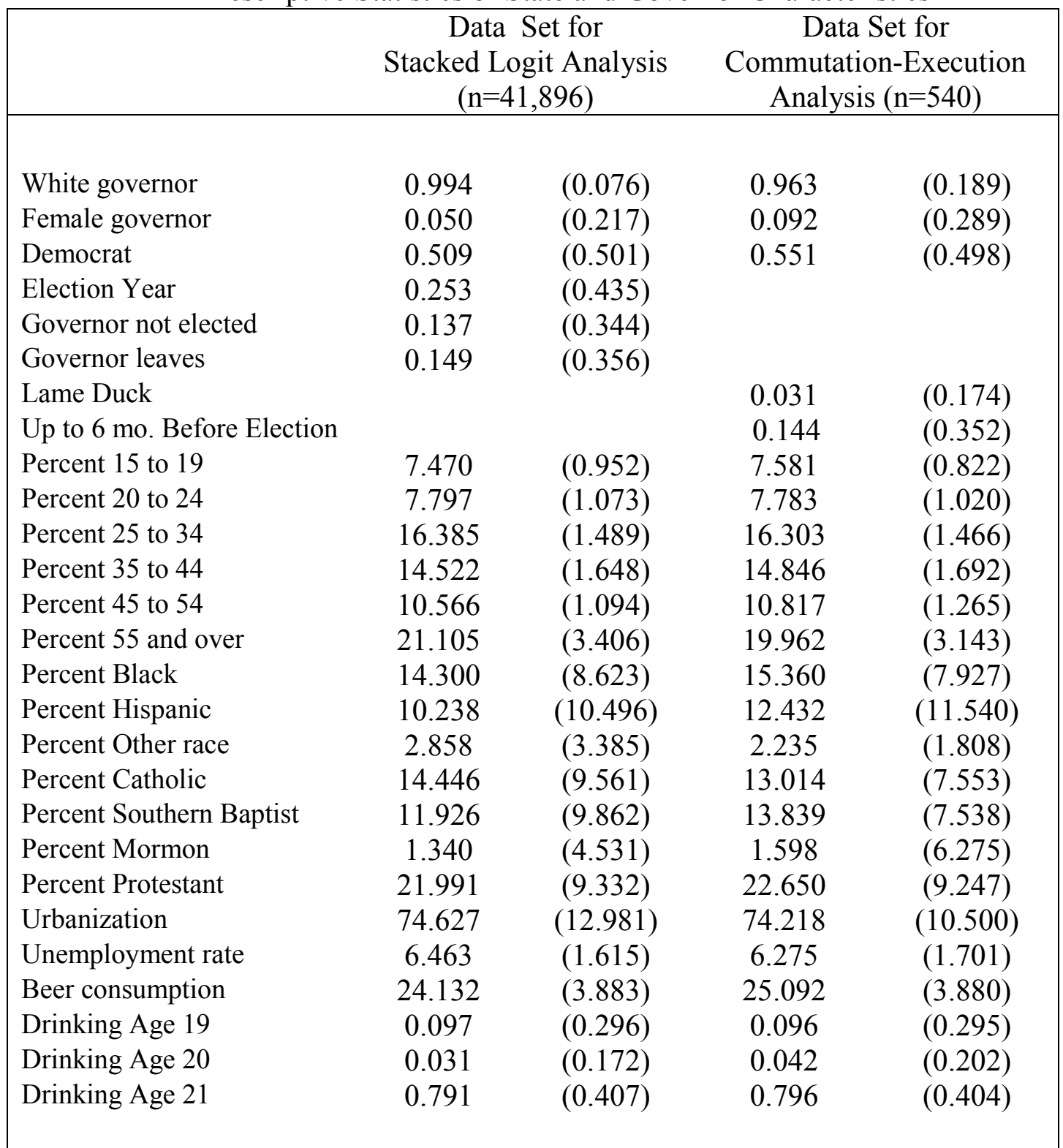

Entries are the means and (standard deviations). 
Table 4

The Determinants of Execution in Any Given Year

\begin{tabular}{|c|c|c|c|c|}
\hline & $\begin{array}{c}\text { (1) } \\
\text { Marginal Effect } \\
\text { x100 }\end{array}$ & $\begin{array}{c}(2) \\
\text { z-statistic }\end{array}$ & $\begin{array}{c}\text { (3) } \\
\text { Marginal Effect } \\
\text { x100 }\end{array}$ & $\begin{array}{c}\text { (4) } \\
\text { Z-statistic }\end{array}$ \\
\hline Black & $-0.073 * *$ & -2.33 & $-0.082 * * *$ & -2.74 \\
\hline Other race & -0.031 & -0.98 & -0.035 & -0.96 \\
\hline Hispanic & 0.102 & 0.67 & 0.192 & 1.22 \\
\hline Female & -0.179 & -1.32 & -0.163 & -1.15 \\
\hline Married & 0.008 & 0.28 & 0.011 & 0.34 \\
\hline Grade school & -0.02 & -0.61 & -0.046 & -1.37 \\
\hline Some high school & 0.032 & 0.9 & 0.016 & 0.45 \\
\hline Attended College & 0.053 & 0.94 & 0.066 & 1.1 \\
\hline Age at sentencing & 0.010 & 1.34 & $0.012 *$ & 1.71 \\
\hline Age at sentencing sq. & 0.000 & -0.87 & 0.000 & -1.18 \\
\hline Time on death row & $0.146^{* * *}$ & 6.37 & $0.148 * * *$ & 6.79 \\
\hline Time on death row sq. & $-0.005 * * *$ & -4.24 & $-0.005 * * *$ & -4.4 \\
\hline Number of spells & $-0.135^{*}$ & -1.7 & $-0.182 * *$ & -2.22 \\
\hline Prior felonies & 0.048 & 1.57 & $0.049^{*}$ & 1.66 \\
\hline White governor & $-0.926 * * *$ & -3.03 & -0.072 & -0.74 \\
\hline Female governor & 0.081 & 1.12 & 0.122 & 1.52 \\
\hline Democrat & $-0.144 * *$ & -2.3 & $-0.114^{*}$ & -1.78 \\
\hline Election Year & -0.014 & -0.23 & -0.027 & -0.5 \\
\hline Governor not elected & 0.108 & 1.46 & 0.094 & 1.31 \\
\hline Governor leaves & 0.029 & 0.63 & 0.017 & 0.45 \\
\hline Percent 15 to 19 & 0.050 & 0.6 & $0.150 *$ & 1.7 \\
\hline Percent 20 to 24 & 0.014 & 0.17 & -0.047 & -0.45 \\
\hline Percent 25 to 34 & 0.055 & 0.79 & 0.035 & 0.36 \\
\hline Percent 35 to 44 & $0.116^{*}$ & 1.75 & 0.113 & 1.32 \\
\hline Percent 45 to 54 & 0.116 & 1.41 & -0.024 & -0.26 \\
\hline Percent 55 and over & 0.011 & 0.28 & -0.036 & -0.62 \\
\hline Percent Black & 0.005 & 0.61 & -0.008 & -0.65 \\
\hline Percent Hispanic & -0.008 & -1.38 & 0.005 & 0.5 \\
\hline Percent Other race & $-0.046 * * *$ & -2.56 & $-0.055^{*}$ & -1.76 \\
\hline Percent Catholic & -0.013 & -1.31 & 0.025 & 0.62 \\
\hline Percent Southern Baptist & -0.021 & -1.51 & -0.04 & -0.6 \\
\hline Percent Mormon & $0.013^{*}$ & 1.81 & $0.147 * * *$ & 3.06 \\
\hline Percent Protestant & 0.004 & 0.68 & 0.018 & 1.41 \\
\hline Urbanization & 0.006 & 0.93 & $0.174 * *$ & 2.33 \\
\hline Unemployment rate & $0.078 * * *$ & 3.39 & $0.066^{* * *}$ & 3.03 \\
\hline Beer consumption & -0.004 & -0.27 & 0.017 & 0.51 \\
\hline Drinking Age 19 & -0.043 & -0.26 & 0.105 & 0.67 \\
\hline Drinking Age 20 & -0.079 & -0.37 & -0.016 & -0.08 \\
\hline Drinking Age 21 & -0.953 & -1.6 & -0.634 & -1.46 \\
\hline Region dummies & Yes & & No & \\
\hline State dummies & No & & Yes & \\
\hline $\mathrm{N}$ & 41,896 & & 38,441 & \\
\hline Log-likelihood & $-1,916.33$ & & $-1,845.54$ & \\
\hline
\end{tabular}

Columns (2) and (4) contain robust standard errors, which are adjusted for clustering at the state level. Marginal effects and standard errors are multiplied by 100 for ease of presentation. Regressions also include dichotomous variables for missing information on education. Marital status, prior felonies and Hispanic origin. *,**, and *** indicate that the coefficient is significant at the $10 \%, 5 \%$, and $1 \%$ level, respectively. 
Table 5

Determinants of Commutation

For Executed or Commuted Prisoners

\begin{tabular}{|c|c|c|c|c|}
\hline & (1) & (2) & (3) & (4) \\
\hline & $\begin{array}{c}\text { Marginal Effects } \\
\text { (z-statistic) }\end{array}$ & $\begin{array}{c}\text { Marginal Effects } \\
\text { (z-statistic) }\end{array}$ & $\begin{array}{c}\text { Marginal Effects } \\
\text { (z-statistic) }\end{array}$ & $\begin{array}{c}\text { Marginal Effects } \\
\text { (z-statistic) }\end{array}$ \\
\hline Black & $0.051 * *$ & $0.058 * *$ & 0.072 & $0.193 * *$ \\
\hline & $(2.05)$ & $(2.08)$ & $(0.6)$ & $(1.98)$ \\
\hline Hispanic & 0.03 & 0.024 & 0.053 & 0.199 \\
\hline & $(1.15)$ & $(1.04)$ & $(0.42)$ & (1.6) \\
\hline Other race & $0.536 * *$ & $0.676 * *$ & $0.579 *$ & $0.867 * *$ \\
\hline & $(2.07)$ & $(2.13)$ & $(1.7)$ & $(2.19)$ \\
\hline Female & $0.705 * * *$ & $0.895 * *$ & $0.704 * * *$ & $0.893 * *$ \\
\hline & $(2.62)$ & $(2.2)$ & $(2.61)$ & $(2.19)$ \\
\hline Married & $0.077 * *$ & 0.029 & $0.077 * *$ & 0.029 \\
\hline & $(2.24)$ & $(1.02)$ & $(2.21)$ & $(1.01)$ \\
\hline Grade School & $0.067^{*}$ & $0.09 * *$ & $0.066^{*}$ & $0.083 * *$ \\
\hline & $(1.86)$ & $(2.54)$ & (1.89) & $(2.47)$ \\
\hline Some High School & -0.011 & 0.020 & -0.012 & 0.017 \\
\hline & $(-0.35)$ & $(0.72)$ & $(-0.38)$ & $(0.61)$ \\
\hline Attended College & $-0.096 * * *$ & $-0.054 * *$ & $-0.096 * * *$ & $-0.054 * *$ \\
\hline & $(-3.15)$ & $(-2.28)$ & $(-3.18)$ & $(-2.32)$ \\
\hline Age at Sentencing & $-0.028 * *$ & $-0.022 *$ & $-0.028 * *$ & $-0.022^{*}$ \\
\hline & $(-2.23)$ & $(-1.95)$ & $(-2.23)$ & $(-1.94)$ \\
\hline Age at Sentencing sq. & $0.0003 *$ & $0.0003 *$ & $0.0003 *$ & $0.0003 *$ \\
\hline & $(1.94)$ & $(1.9)$ & $(1.95)$ & $(1.88)$ \\
\hline Time on Death Row & 0.008 & -0.008 & 0.008 & -0.008 \\
\hline & $(0.52)$ & $(-0.64)$ & $(0.51)$ & $(-0.67)$ \\
\hline Time on Death Row sq. & -0.001 & -0.0001 & -0.001 & -0.0001 \\
\hline & $(-1.34)$ & $(-0.17)$ & $(-1.34)$ & $(-0.15)$ \\
\hline Number of Spells & -0.016 & $-0.052 *$ & -0.016 & $-0.049^{*}$ \\
\hline & $(-0.27)$ & $(-1.76)$ & $(-0.27)$ & $(-1.73)$ \\
\hline Prior Felonies & -0.031 & -0.022 & -0.03 & -0.021 \\
\hline & $(-0.74)$ & $(-0.66)$ & $(-0.73)$ & $(-0.64)$ \\
\hline White Governor & $-0.172 *$ & $-0.55^{* *}$ & -0.189 & $-0.623 * *$ \\
\hline & $(-1.71)$ & $(-2.29)$ & $(-1.55)$ & $(-2.46)$ \\
\hline White Governor x & & & 0.021 & 0.096 \\
\hline White inmate & ---- & & $(0.18)$ & $(1.19)$ \\
\hline Female Governor & $0.195 * *$ & $0.337 * *$ & $0.196 * *$ & $0.346 * *$ \\
\hline & $(2.01)$ & $(2.08)$ & $(2.01)$ & $(2.06)$ \\
\hline Democrat & 0.005 & 0.029 & 0.005 & 0.028 \\
\hline & $(0.11)$ & $(0.44)$ & $(0.1)$ & $(0.43)$ \\
\hline Up to 6 months before & -0.01 & 0.019 & -0.01 & 0.018 \\
\hline Election & $(-0.24)$ & $(0.4)$ & $(-0.24)$ & $(0.37)$ \\
\hline Lame Duck & $0.402 * * *$ & $0.456 * *$ & $0.404 * * *$ & $0.462 * *$ \\
\hline & $(2.66)$ & $(2.05)$ & $(2.6)$ & $(2)$ \\
\hline Percent 15 to 19 & 0.015 & -0.105 & 0.016 & -0.103 \\
\hline & $(0.24)$ & $(-1.55)$ & $(0.25)$ & $(-1.5)$ \\
\hline
\end{tabular}


(Table 5 concluded)

\begin{tabular}{|c|c|c|c|c|}
\hline Percent 20 to 24 & $\begin{array}{c}-0.152 * * * \\
(-2.99)\end{array}$ & $\begin{array}{c}-0.136^{*} \\
(-1.92)\end{array}$ & $\begin{array}{c}-0.151 * * * \\
(-2.96)\end{array}$ & $\begin{array}{c}-0.135^{*} \\
(-1.9)\end{array}$ \\
\hline Percent 25 to 34 & $\begin{array}{c}0.114 * * \\
(2.37)\end{array}$ & $\begin{array}{c}0.158 * * \\
(2.49)\end{array}$ & $\begin{array}{c}0.115^{* *} \\
(2.39)\end{array}$ & $\begin{array}{c}0.161^{* *} \\
(2.5)\end{array}$ \\
\hline Percent 35 to 44 & $\begin{array}{c}-0.205^{* * *} \\
(-4.08)\end{array}$ & $\begin{array}{c}-0.275^{* * *} \\
(-3.81)\end{array}$ & $\begin{array}{c}-0.204 * * * \\
(-4.07)\end{array}$ & $\begin{array}{c}-0.272 * * * \\
(-3.76)\end{array}$ \\
\hline Percent 45 to 54 & $\begin{array}{c}0.156^{* * *} \\
(3.67)\end{array}$ & $\begin{array}{c}0.30 * * * \\
(4.05)\end{array}$ & $\begin{array}{c}0.157 * * * \\
(3.7)\end{array}$ & $\begin{array}{l}0.3 * * * \\
(4.05)\end{array}$ \\
\hline Percent 55 and over & $\begin{array}{l}-0.015 \\
(-0.65)\end{array}$ & $\begin{array}{c}0.088^{*} \\
(1.73)\end{array}$ & $\begin{array}{l}-0.015 \\
(-0.64)\end{array}$ & $\begin{array}{l}0.087^{*} \\
(1.72)\end{array}$ \\
\hline Percent Black & $\begin{array}{l}-0.009 \\
(-1.14)\end{array}$ & $\begin{array}{l}0.008 \\
(1.09)\end{array}$ & $\begin{array}{l}-0.009 \\
(-1.12)\end{array}$ & $\begin{array}{l}0.008 \\
(1.16)\end{array}$ \\
\hline Percent Hispanic & $\begin{array}{l}0.006 \\
(0.84)\end{array}$ & $\begin{array}{l}-0.003 \\
(-0.41)\end{array}$ & $\begin{array}{l}0.006 \\
(0.86)\end{array}$ & $\begin{array}{l}-0.002 \\
(-0.31)\end{array}$ \\
\hline Percent Other Race & $\begin{array}{c}-0.045^{* * *} \\
(-2.78)\end{array}$ & $\begin{array}{c}-0.063^{*} \\
(-1.94)\end{array}$ & $\begin{array}{c}-0.045^{* * *} \\
(-2.81)\end{array}$ & $\begin{array}{c}-0.064^{*} \\
(-1.95)\end{array}$ \\
\hline Percent Catholic & $\begin{array}{c}0.014^{*} \\
(1.7)\end{array}$ & $\begin{array}{l}-0.002 \\
(-0.07)\end{array}$ & $\begin{array}{l}0.014^{*} \\
(1.71)\end{array}$ & $\begin{array}{l}-0.005 \\
(-0.18)\end{array}$ \\
\hline Percent Southern Baptist & $\begin{array}{c}0.017^{*} \\
(1.8)\end{array}$ & $\begin{array}{l}0.064 \\
(1.23)\end{array}$ & $\begin{array}{c}0.017^{*} \\
(1.8)\end{array}$ & $\begin{array}{l}0.065 \\
(1.26)\end{array}$ \\
\hline Percent Mormon & $\begin{array}{c}-0.009^{*} \\
(-1.75)\end{array}$ & $\begin{array}{l}0.111 \\
(1.23)\end{array}$ & $\begin{array}{c}-0.009^{*} \\
(-1.74)\end{array}$ & $\begin{array}{l}0.114 \\
(1.27)\end{array}$ \\
\hline Percent Protestant & $\begin{array}{l}-0.001 \\
(-0.17)\end{array}$ & $\begin{array}{c}-0.003 \\
(-0.3)\end{array}$ & $\begin{array}{l}-0.001 \\
(-0.18)\end{array}$ & $\begin{array}{l}-0.003 \\
(-0.26)\end{array}$ \\
\hline Urbanization & $\begin{array}{l}-0.008 \\
(-1.42)\end{array}$ & $\begin{array}{l}-0.032 \\
(-0.79)\end{array}$ & $\begin{array}{l}-0.008 \\
(-1.45)\end{array}$ & $\begin{array}{l}-0.033 \\
(-0.82)\end{array}$ \\
\hline Unemployment Rate & $\begin{array}{c}-0.028 \\
(-1.6)\end{array}$ & $\begin{array}{c}-0.013 \\
(-0.9)\end{array}$ & $\begin{array}{l}-0.028 \\
(-1.59)\end{array}$ & $\begin{array}{c}-0.012 \\
(-0.8)\end{array}$ \\
\hline Beer Consumption & $\begin{array}{l}-0.011 \\
(-1.36)\end{array}$ & $\begin{array}{c}-0.036^{*} \\
(-1.77)\end{array}$ & $\begin{array}{l}-0.011 \\
(-1.37)\end{array}$ & $\begin{array}{c}-0.035^{*} \\
(-1.66)\end{array}$ \\
\hline Drinking Age 19 & $\begin{array}{l}-0.039 \\
(-0.58)\end{array}$ & $\begin{array}{l}-0.048 \\
(-0.85)\end{array}$ & $\begin{array}{l}-0.038 \\
(-0.57)\end{array}$ & $\begin{array}{l}-0.046 \\
(-0.82)\end{array}$ \\
\hline Drinking Age 20 & $\begin{array}{l}-0.05 \\
(-0.58)\end{array}$ & $\begin{array}{l}0.029 \\
(0.38)\end{array}$ & $\begin{array}{l}-0.049 \\
(-0.58)\end{array}$ & $\begin{array}{l}0.023 \\
(0.32)\end{array}$ \\
\hline Drinking Age 21 & $\begin{array}{l}0.072 \\
(1.01)\end{array}$ & $\begin{array}{l}0.086 \\
(1.25)\end{array}$ & $\begin{array}{l}0.072 \\
(1.01)\end{array}$ & $\begin{array}{l}0.083 \\
(1.19)\end{array}$ \\
\hline Region dummies & Yes & No & Yes & No \\
\hline State dummies & No & Yes & No & Yes \\
\hline $\mathrm{N}$ & 540 & 503 & 540 & 503 \\
\hline Log-likelihood & -140.99 & -109.56 & -140.98 & -109.27 \\
\hline
\end{tabular}

The entries are marginal effects. Robust standard errors are adjusted for clustering at the state level. Z-statistics are reported in parentheses. Regressions also include dichotomous variables for missing information on education. Marital status, prior felonies and Hispanic origin. *, **, and *** indicate that the coefficient is significant at the $10 \%, 5 \%$, and $1 \%$ level, respectively. 
Figure 1

Executions in the United States

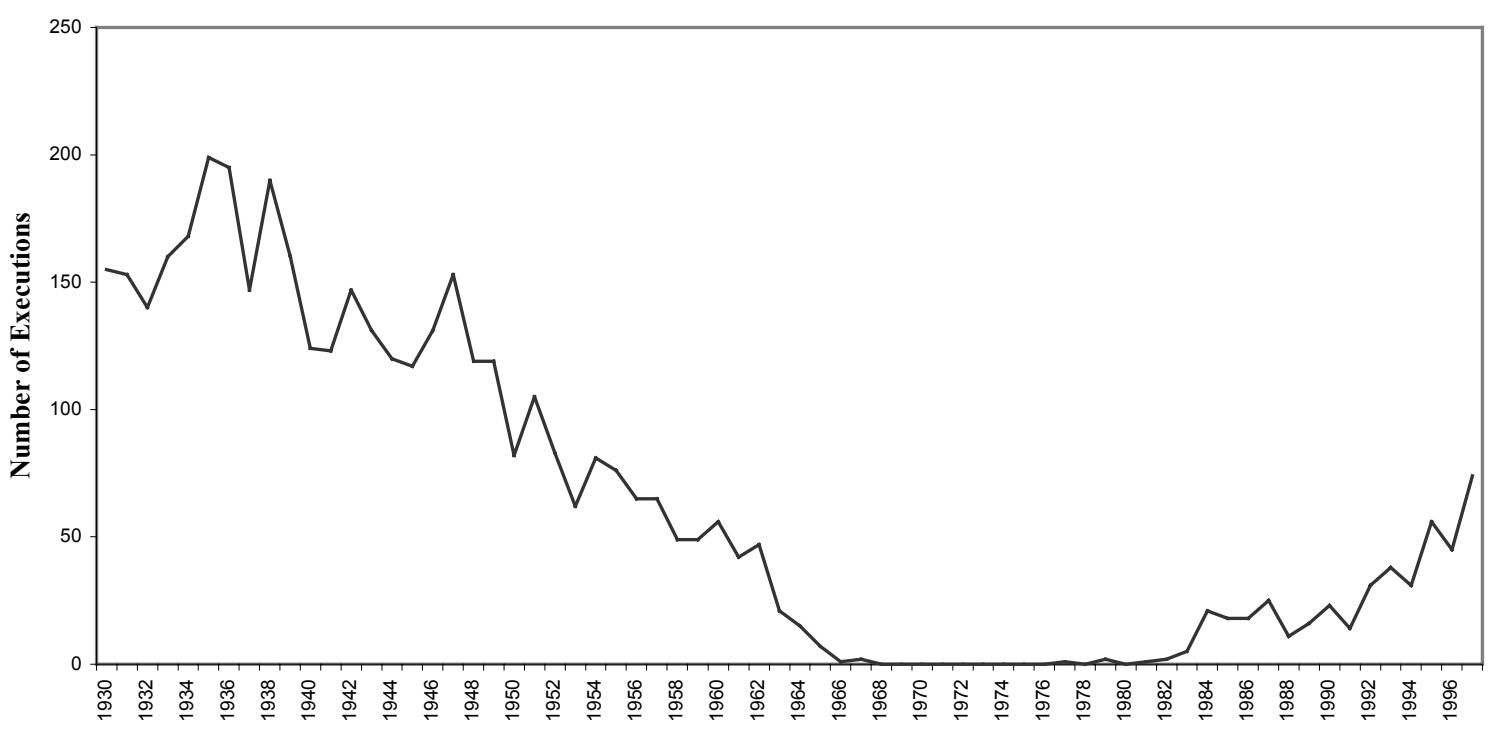

Figure 2

Racial Distribution of Prisoners on Death Row 1968 - 1998

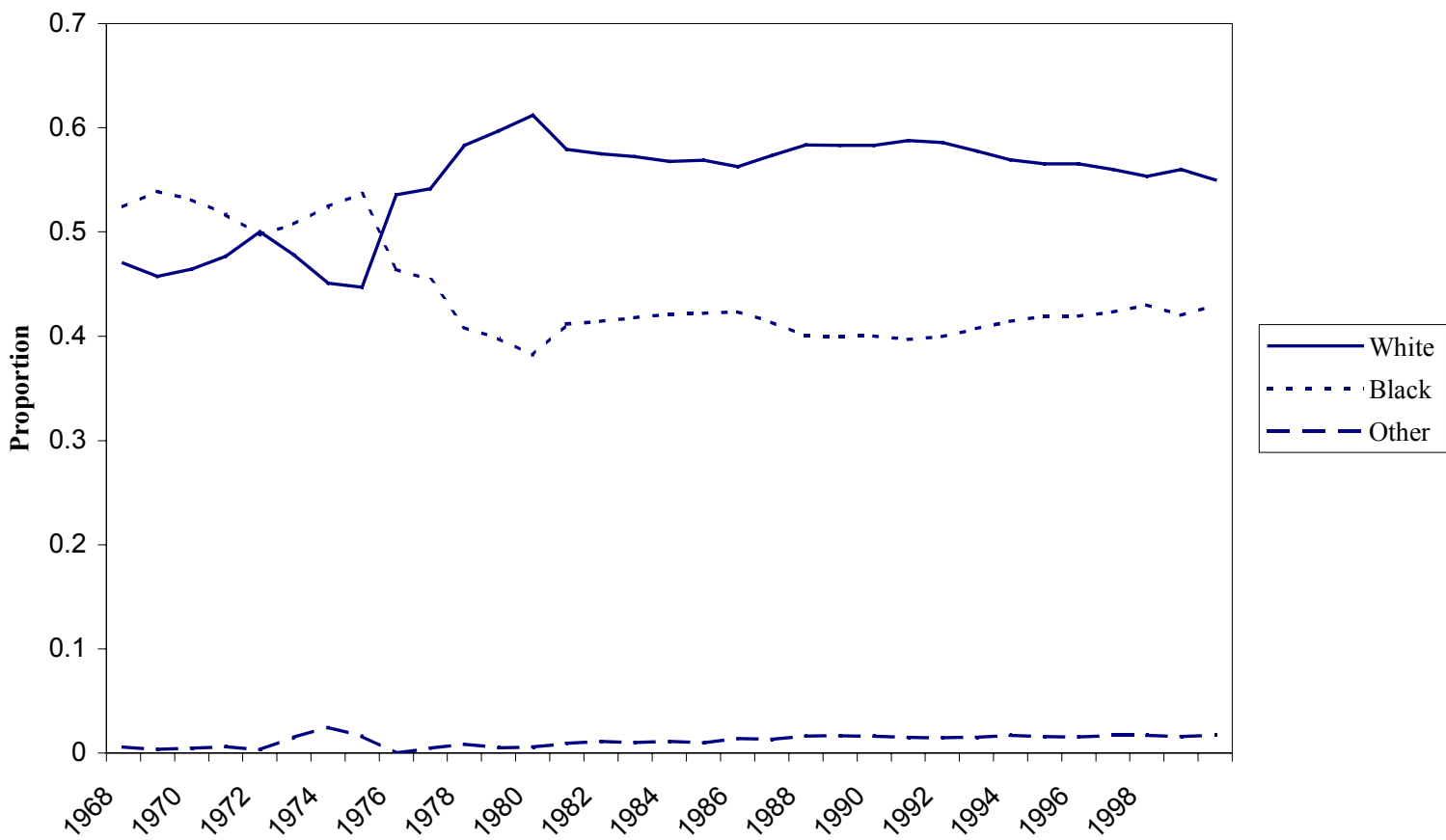


Figure 3

Prisoners on Death Row

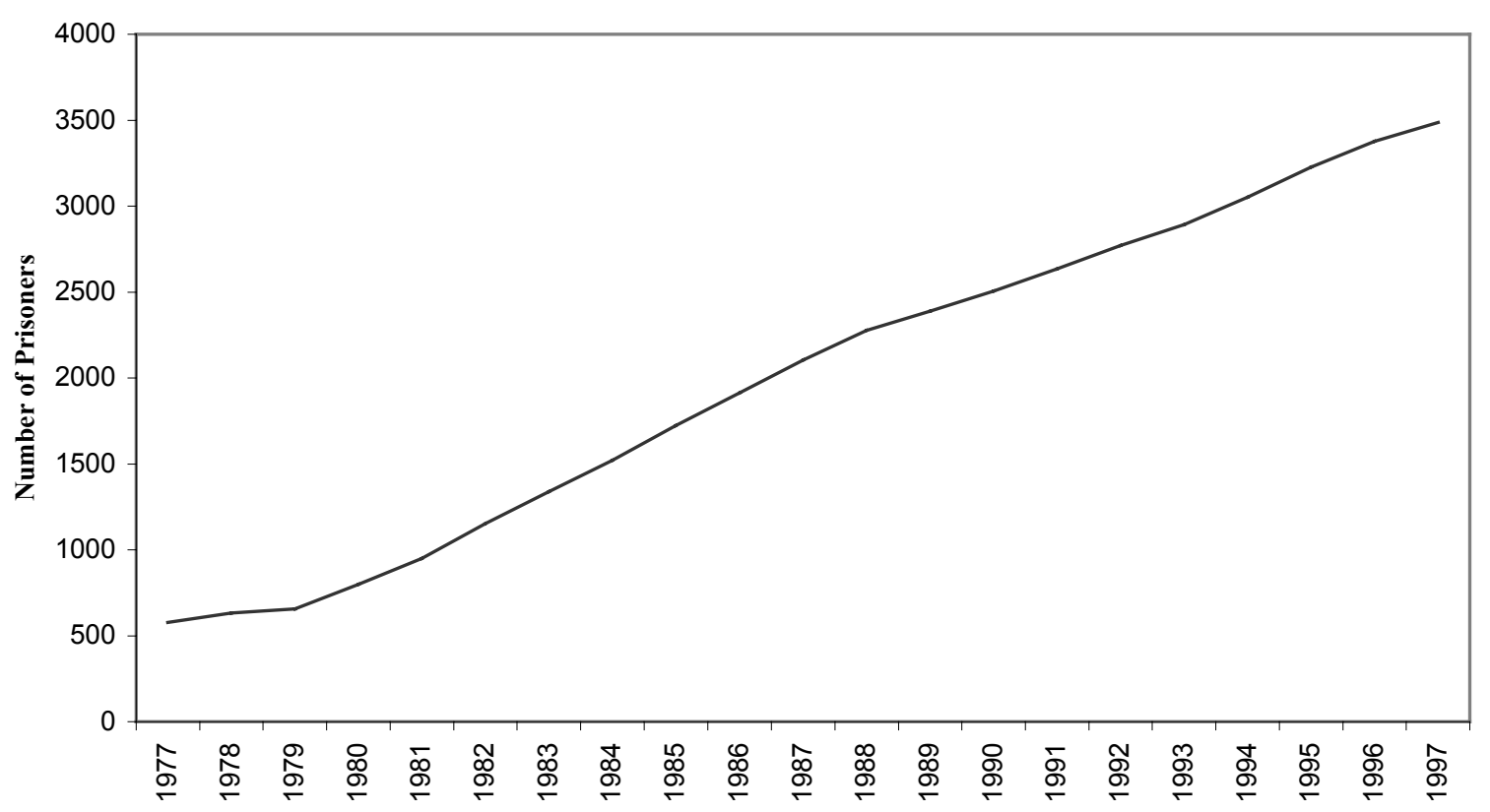

Figure 4

Average Duration on Death Row Resulting in Execution or Commuted Sentence

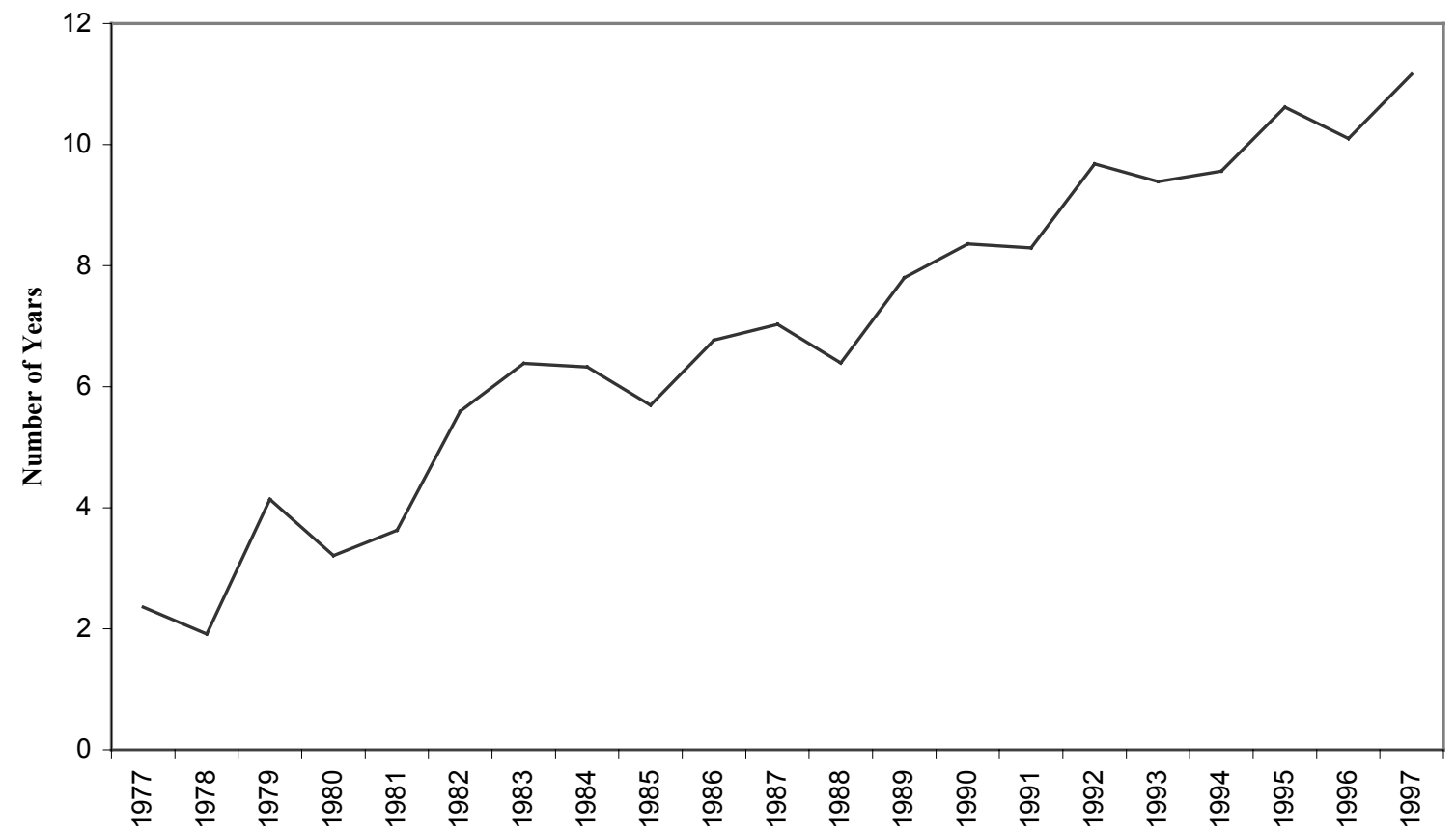


Figure 5

Average Duration on Death Row Resulting in Execution

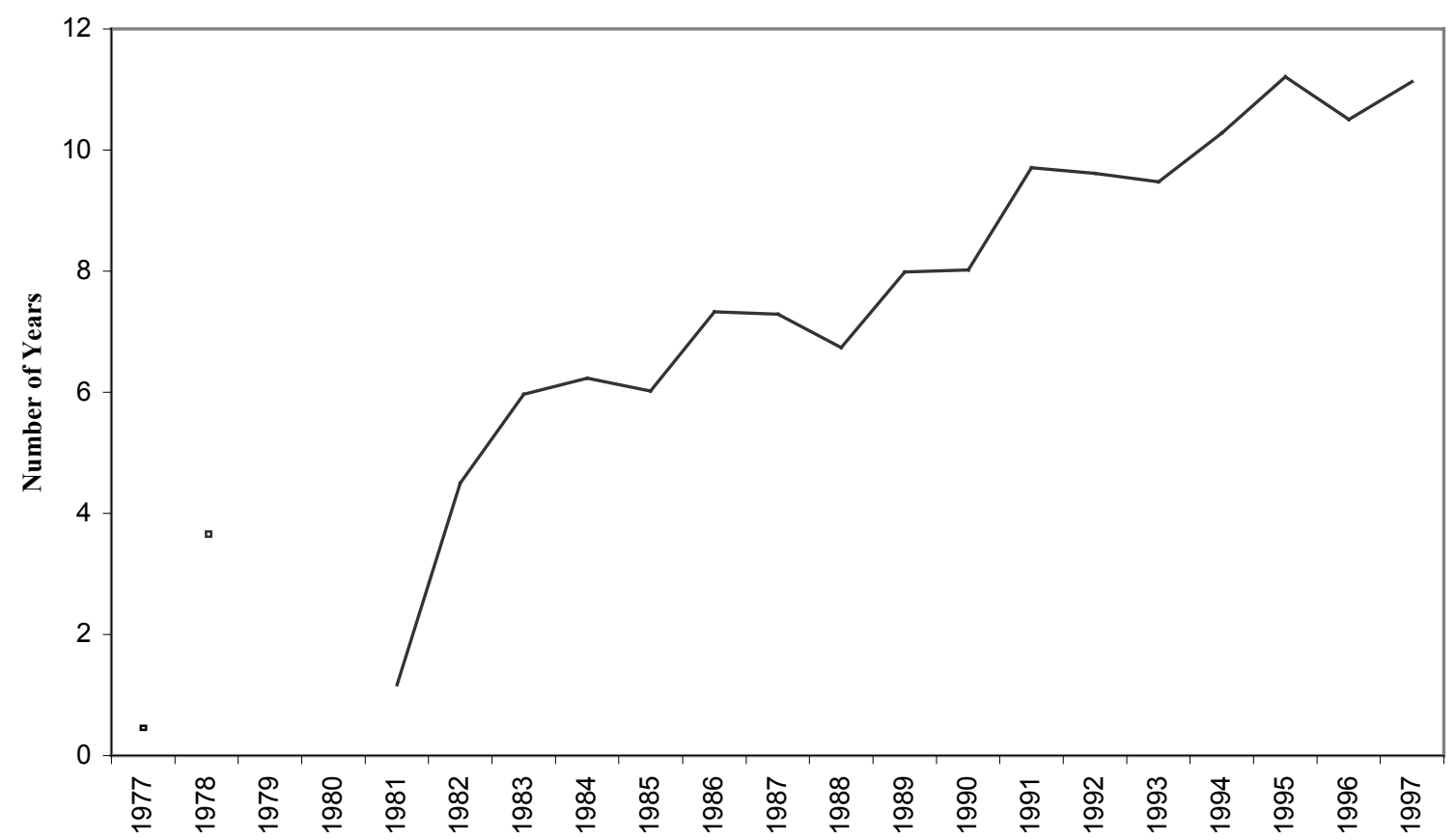

Figure 6

Number of Executions and Commuted Sentences

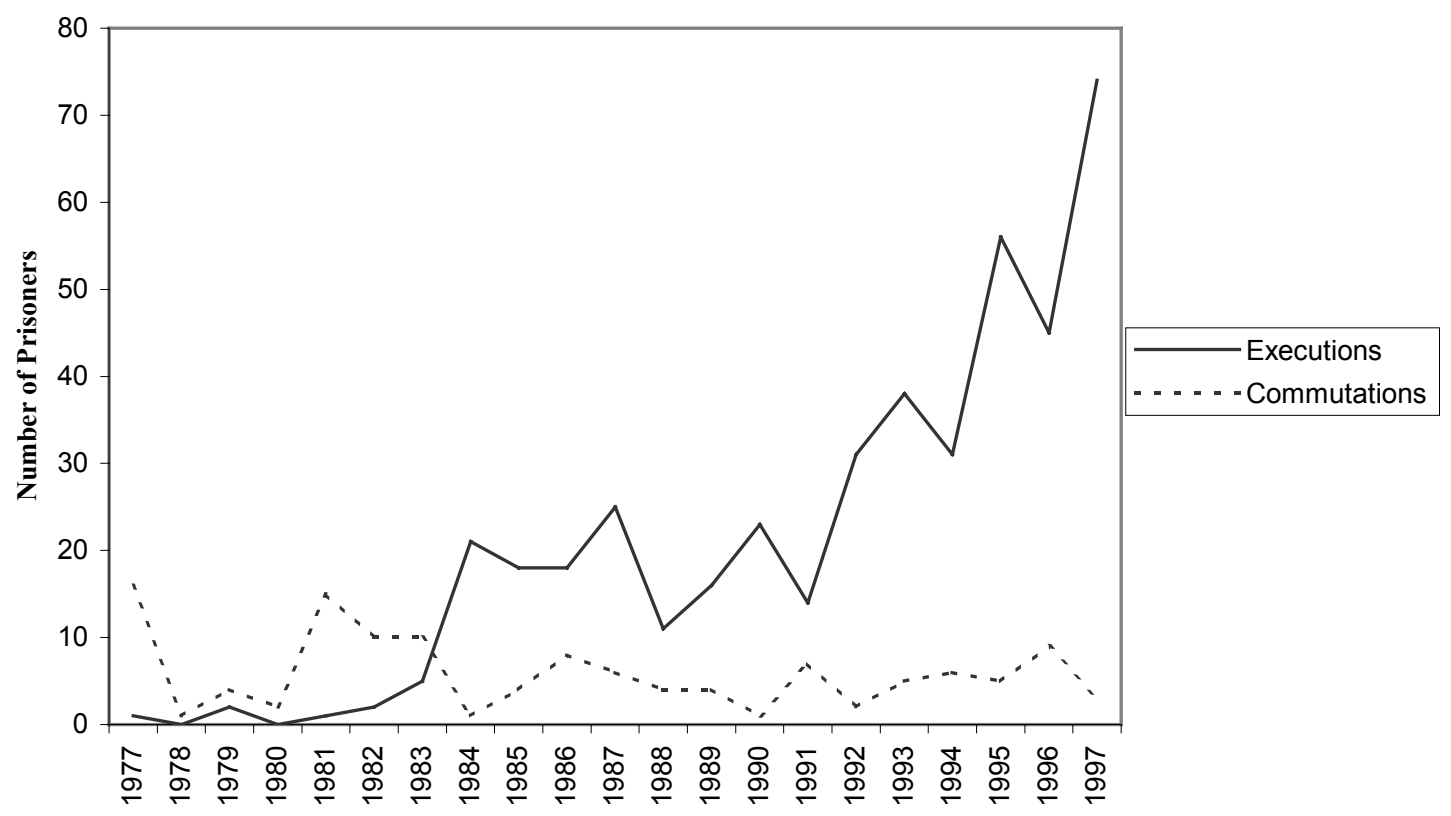




\section{Data Sources}

\section{$\underline{\text { Data on Death Row Inmates }}$}

U.S. Dept. of Justice, Bureau of Justice Statistics. Capital Punishment in the United States, 1973-1998 [Computer file]. Compiled by the U.S. Dept. of Commerce, Bureau of the Census. ICPSR ed. Ann Arbor. MI: Inter-university Consortium for Political and Social Research [producer and distributor], 2000.

\section{State Data}

Total State Population and Age Representation: U.S. Census Bureau, Population Division, Population Distribution Branch [electronic file].

Ethnic Population Representation: Estimated using the March Current Population Survey data. Unemployment Rate: Local Area Unemployment Statistics, Bureau of Labor Statistics [electronic file]. Not Seasonally Adjusted. 1977 data for all states and years 1978 and 1979 for California were completed using The Statistical Abstract of the United States.

Urbanization: "Urban and Rural Population: 1900 to 1990". U.S. Census Bureau [electronic files]. The files provided percent urbanization data for all states for 1970, 1980 and 1990. Values were linearly interpolated for the 1970s and 1980s. The same change in urbanization for the 1980's were used to calculate the urbanization numbers for the 1990s.

Governor Data: Gubernatorial Elections (1998).

Beer Consumption is from Brewers Almanac published by the Beer Institute. 


\section{References}

Baldus, D. et al., 1998, "Race Discrimination and the Death Penalty in the Post Furman Era: An Empirical and Legal Overview with Preliminary Findings from Philadelphia, Cornell Law Review; 83, pp. 1638-1770.

Jackson, Jesse, 1996, Legal Lynching; New York: Marlowe \& Co.

Kleck, Gary, 1981, "Racial Discrimination in Criminal Sentencing: A Critical Evaluation of the Evidence with Additional Evidence on the Death Penalty," American Sociological Review, 46:1, pp. 783

Kubik, Jeffrey and John Moran, 2002, "Lethal Elections: Gubernatorial Politics and the Timing of Executions," miemo, Syracuse Univesity.

Gross, Samuel and Robert Mauro, 1984, "Patterns of Death: An Analysis of Racial Disparities in Capital Sentencing and Homicide Victimization," Stanford Law Review, 37, pp 27-153.

Lott, John R., 1992, “Do We Punish High Income Criminals Too Heavily?” Economic Inquiry, pp. 583-608

Lott, John R., 1987, "Should the Wealthy Be Able to "Buy Justice"?," Journal of Political Economy, 95:6, pp. 1307-16.

Paternoster, Raymond, 1984, "Prosecutorial Discretion in Requesting the Death Penalty: A case of Victim-Based Racial Discrimination," Law and Society Review, 18:3, pp. 437

Pokorak, J., 1998, "Probing the Capital Prosecutor's Perspective: Race and Gender of the Discretionary Actors, Cornell Law Review; 83: 6.

Pridemore, William Alex, 2000, "An Empirical Examination of Commutations and Executions in Post-Furman Capital Cases," Justice Quarterly; 17:1, pp. 159-83.

Raport, Elizabeth, 1991, "The Death Penalty and Gender Discrimination," Law and Society Review

Steiker Carol S., and Jordan M. Steiker, 1995, "Sober Second Thoughts: Reflections on Two Decades of Constitutional Regulation of Capital Punishment," Harvard Law Review, 109:2, pp. 357-438.

U.S. Bureau of Census, 2002. Statistical Abstract of the U.S.

U.S. Department of Justice; Bureau of Justice Statistics. Sourcebook of Criminal Justice Statistics; 2002.

U.S. Department of Justice; Bureau of Justice Statistics. Capital Punishment; 2000. 
Wolfgang, Marvin E. and Marc Riedel, 1973, "race Judicial Discretion and the Death Penalty," The Annals of the American Academy of Political and Social Science, 407, pp. 119-33.

Zeisel, Hans, 1981, "Race Bias in the Administration of the Death Penalty: The Florida Experience," Harvard Law Review, 95:2 pp. 456-68. 